How will big pictures emerge from a sea of biological data?

\title{
从生物大数据到知识大发现: 十年进展与未来展望
}

张学工*，江瑞，汪小我，古槿，陈挺

(1) 清华大学自动化系, 计算机科学与技术系, 生命科学学院, 教育部生物信息学重点实验室, 北京 100084 ;

(2) 清华信息科学与技术国家实验室生物信息学研究部, 北京 100084 ;

(3) 清华大学数据科学研究院医疗健康大数据研究中心, 北京 100084

* 联系人, E-mail: zhangxg@ @tsinghua.edu.cn

2016-08-18 收稿, 2016-09-14 修回, 2016-09-14 接受, 2016-11-23 网络版发表

国家重点基础研究发展计划(2012CB316500)资助

摘要生物和医疗大数据的快速大量积累是当今生命科学领域的一个重要特征, 但从这些大数据能否获得关于 生命现象规律的重大知识发现，是人们更关心的关键问题，也是2005年Science 杂志展望的 125 个最具挑战性问题 之一, 本文从新一代DNA测序技术发展以及医学遗传学、合成生物学、精准医学、微生物组学等几个方面, 回顾 了近十年来生物大数据的重要发展和已经由此带来的科学进步, 并对未来的发展方向进行了展望.

关键词生物大数据, 基因组学, 生物信息学, 系统生物学, 组学

15年前，2001年2月15日Nature杂志发表了长达 62 页的论文《人类基因组的初始测序与分析》 ${ }^{[1]}$, 标 志着历时十几年、耗资约 27 亿美元的人类基因组计划 初步完成, 人类对生命科学的探索进人了一个新的 时代. 在人类基因组计划开始初期，还有人怀疑花费 如此巨大的人力物力获取人类基因组数据是否有价 值，但这种怀疑很快被打破，以DNA测序、基因芯 片、生物信息学算法等为代表的大规模生物数据获取 与处理技术, 迅速登上了生命科学的核心舞台, 数据 成为生命科学研究的基本资源. 2005年7月, Science 杂志在纪念创刊 125 周年之际刊登了 125 个最具挑战 性的科学问题, 其中一个重要的问题就是, 怎样才能 从生物数据的海洋中获得生物学的大图景(How will big pictures emerge from a sea of biological data?) ${ }^{[2]}$. 文章指出, 基于海量生物学数据的系统生物学研究 被认为是获得对复杂生命系统全面认识的必由之路, 将对生物医学尤其是理解疾病的风险因素产生巨大 作用. 但是, 人们尚不知道, 这种数学、工程学与生
物学高度交叉的研究以及迅速提升的计算能力, 是 否能够对生命的工作机理带来深人的、高度结构化的 全面认识 ${ }^{[2]}$. 又一个十年过去了, 在这十年里, 生物 数据的获取和分析技术都取得了突飞猛进的发展, 我们有必要重新审视一下当初提出的这个挑战, 回 顾人类朝向用数据去理解生命奥秘这一目标所迈出 的步伐.

\section{1 新一代测序技术快速发展}

在过去的十年里, 生物和医学领域一个引人瞩目 的发展，是新一代测序技术的快速发展和由此带来的 一系列应用. 21 世纪初完成的人类基因组计划, 全世 界几十个实验室合作花费了十几年时间，耗资近30亿 美元. 2005年开始，以大规模并行测序为特点的第二 代测序技术得到了突飞猛进的发展, 以单分子实时测 序为特点的第三代测序技术也迅速崛起, 到目前为止, 很多测序机构已经能够用 1000 美元以下的成本完成一 个人的全基因组测序. 已经有人开始大胆地预测，测 
序一个人的基因组的成本将会降到一百美元以下.

新一代测序技术的发展, 为现代生命科学研究 带来了多方位的革命, 数据成为很多研究的核心. 一 方面, 完成基因组测序的物种数目迅速增加; 另一方 面, 对人群的遗传多样性的研究也进一步深人. 千人 基因组计划(1000 Genomes Project)已经完成 ${ }^{[3]}$, 大量 全外显子测序计划迅速开展 ${ }^{[4]}$, 在各种公共数据库中 已经积累了至少 2504 个人类个体的全基因组数据 ${ }^{[3]}$ 、 涉及 1302002 个个体的全基因组关联分析(GWAS)数 据 ${ }^{[5]}$ (http://www.ncbi.nlm.nih.gov/gap/) 、涉及60706个 个体的全外显子测序数据 (http://exac.broadinstitute. org/)等. 美国2015年启动精准医学计划, 拟针对癌症 采集一百万人规模的基因组数据. 人们对人类遗传 多样性的研究, 已经从集中在对人群中发生频率 $5 \%$ 以上的遗传多态性位点的研究, 扩展到对发生频率 在 $1 \%$ 甚至 $0.1 \%$ 的遗传多态性位点的研究 ${ }^{[4]}$.

新一代测序技术的应用远远不止于对基因组 DNA序列的测序, 而是通过与其他多种技术的结合 深人到分子和系统生物学的各个方面. 通过反转录 进行RNA测序, 已经迅速成为继基因芯片之后研究 转录组的主要技术手段, 为研究基因表达、基因的选 择性剪接和非编码基因提供了有效手段. 通过与染 色质免疫沉降技术结合的ChIP-Seq技术, 可以高分 辨率获取转录因子等DNA结合蛋白在基因组上的结 合位点, 为解读复杂的基因转录调控系统打开了一 个重要缺口; 可以获得各种组蛋白修饰的全基因组 图谱, 揭示组蛋白修饰对基因转录、组织特异性表达 等的组合调控作用. 通过对 RNA结合蛋白的抓取, CLIP-Seq技术可以获得RNA转录后调控因子在RNA 上的结合位点, 精确揭示RNA调控. 通过亚硫酸盐 测序(Bisulfite-Seq), 可以对全基因组范围内的DNA 甲基化进行高分辨率检测. 通过染色质构象捕获技 术 $(3 \mathrm{C}, \mathrm{Hi}-\mathrm{C})$ 及其扩展技术, 可以获得基因组三维结 构和长程相互作用等. 这些技术, 很多已经发展到能 够对单个细胞或少量细胞进行观测, 出现了单细胞 DNA测序、单细胞RNA测序、单细胞基因组和RNA 联合测序等单细胞测序技术, 为精细研究干细胞发 育和分化、癌症发生发展等重要过程中的细胞异质性 提供了有效的研究手段. 与此同时, 以单分子实时测 序为代表特点的第三代测序技术也在不断发展和走 向成熟, 通过第三代测序技术, 不但能够直接读取很 长的DNA或RNA片段, 还能够通过实时的DNA合成
过程中的动态数据推断DNA修饰，为同时读取基因 组序列和表观遗传修饰信息开辟了新的道路.

这些新技术的发展，使得各种基因组学、表观基 因组学、转录组学和微生物群落宏基因组学数据迅速 增加. 2008年启动的千人基因组计划到 2015 年已经完 成, 在其最新的数据中已包含了来自 26 个人种 2504 个个体的全基因组数据, 世界各国启动了多个目标 在几十万到上百万人的全基因组测序计划. 在美国 NCBI用于存储公开的测序数据的数据库SRA中, 到 2016年数据总量已经达到 $5 \times 10^{15}$ 碱基的数量级.

\section{2 测序数据大大推动了医学遗传学发展}

随着测序通量的提高和测序成本的降低，外显 子组测序技术和全基因组测序技术在解析人类疾病 致病遗传因素的研究中获得了广泛应用 ${ }^{[6 \sim 9]}$. 外显子 组测序通过捕获和富集外显子区域DNA再进行高通 量测序来检测发生在蛋白质编码区的遗传变异, 具 有成本相对较低、灵敏度高、可解释性强等优点, 不 仅是鉴定罕见疾病致病遗传因素最有效的策略, 还 被成功应用于复杂疾病易感基因的研究和临床诊断 中. 基于外显子组测序技术，目前已成功检测了导致 米勒综合征 ${ }^{[10]}$ 、儿童自闭症 ${ }^{[11]}$ 、肌萎缩性侧索硬化(渐 冻人 $)^{[12,13]}$ 、精神分裂症 ${ }^{[14]}$ 、心血管疾病 ${ }^{[15] 、}$ 糖尿

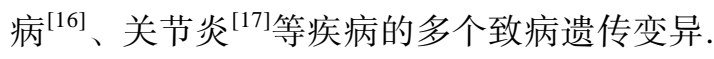

全基因组测序通过对个人DNA序列进行扩增和 高通量测序来检测所有可能的遗传变异, 具有覆盖 面广的优点, 不仅可以检测大量的单核苷酸变异, 还 能检测插人删除位点、结构变异位点和拷贝数变异片 段. 随着测序成本的快速降低, 全基因组测序已经被 越来越广泛地应用于遗传疾病的研究中. 这种基于 全基因组测序的遗传学研究, 目前已在混合性软骨 瘤病 ${ }^{[18]}$ 、腓侧肌萎缩 ${ }^{[19]}$ 等罕见疾病以及婴儿癫㾁

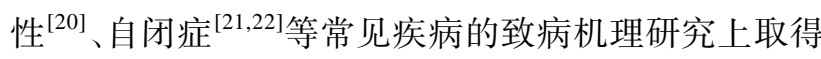
显著进展.

除了科研应用, 外显子组测序和全基因组测序 作为遗传学检测的重要手段, 近两年来已开始被应 用于基因检测以辅助临床诊断 ${ }^{[23,24]}$.

\section{3 基因组学的发展推动了基因组编辑与合 成生物学的革命}

随着基因组研究的快速发展, 近年来基因编辑 
技术得到了多项重要突破, 人们对基因组信息的研 究从“只读模式”开始迈向 “读写模式”. 以 TALE和 CRISPR/Cas为代表的基因组编辑方法极大地改变了 人们研究功能基因组尤其是哺乳动物基因功能的方 式 ${ }^{[25]}$. 以CRISPR系统为例, 它最早被发现是一种细 菌中用于抵抗外来噬菌体病毒的一种获得性免疫机 制 ${ }^{[26]}$. 通过改造后的CRISPR/Cas系统在人工设计合

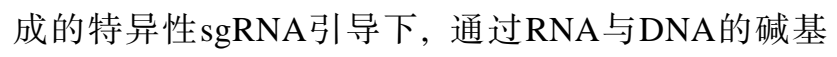
配对, 可以定点切割基因组DNA, 从而可以定点导 致目标基因功能失活, 或在特定位置插人外源基因 序列 ${ }^{[27]}$. 应用这一技术, 通过对胚胎细胞基因组编 辑实现对动物甚至人的基因组进行人工改写已经成 为可能, 这项技术因此受到科学家和全社会的广泛 关注 ${ }^{[28]}$. 但实际上, 基因编辑技术的应用非常广泛, 比如, 人们将这种方法与 DNA芯片合成及测序技术 相结合, 开发出了功能强大的高通量基因功能笁选 方法 ${ }^{[29]}$. 基本思路为针对每一个基因人工设计若干 个能敲除该基因的 sgRNA序列. 利用基因芯片的寡 核苷酸序列并行合成技术, 在芯片上一次性合成 10 万余种的不同DNA序列, 每种DNA序列编码一种特 定的sgRNA. 通过克隆建立携带这些编码sgRNA序 列的质粒文库, 用慢病毒包装后感染目的细胞. 通过 调整病毒感染的效能, 可以使得每个被感染细胞平 均只携带一种 sgRNA编码序列, 即该细胞内只有这 种sgRNA对应的基因被敲除. 这样通过细胞群体中 含有的 sgRNA编码序列的高通量测序, 就可以知道 带有这种特定基因敲除的细胞在群体中所占的比例. 比较使用不同药物作用下细胞群体中携带各种 sgRNA编码序列比例的变化, 经统计学模型计算, 就 可以知道携带哪些类型基因敲除的细胞其增殖速率 相对较快(较慢), 从而推测这些基因在该种药物作用 下促进(抑制)细胞增殖 ${ }^{[29]}$. 这种方法可以用来高通量 篮选在特定因素或药物作用下的靶点和功能基因 ${ }^{[30]}$, 大大加快了人们对药物靶点基因的篮选能力.

以DNA序列合成、组装以及基因组编辑等为代 表的合成生物学新技术为我们定量研究基因网络的 调控机理提供了新的途径和思路. 例如, 我们可以利 用苂光蛋白等报告基因构建人工合成的基因线路并 将其植人细胞内, 如同传感器一样来感知分子浓度 的变化, 实现对细胞状态的实时定量观测. 由于人工 合成基因线路具有可控、可调的特点, 通过改变人工 基因线路的作用方式和强度, 可以帮助我们理解不
同的参数和网络结构对基因调控的影响，从而建立 定量的数学模型来描述分子调控的本质规律 ${ }^{[31]}$. 例 如, 我们将系统生物学建模分析与合成生物学实验 相结合, 建立了 microRNA调控的数学模型, 构建对 应的合成基因线路并植人细胞中模拟microRNA靶基 因的竞争性调控效应, 证实了靶RNA和microRNA浓 度对竞争性调控效应的國值现象, 发现了 microRNA 的靶位点结合能力对竞争性调控效应强度影响的函 数关系, 阐述了 microRNA通路和RNAi通路竞争效应 的不对称性, 并从理论上提出了RNAi技术的改进方 向, 为理解复杂的microRNA调控系统和未来用RNAi 技术有效设计疾病基因靶向治疗等提供了理论基 础 $^{[32]}$. 又如, 通过这样“以建而学”的方式, 研究人员 提出了艾滋病病毒 (HIV) 潜伏和激活的随机模 型 ${ }^{[33,34]}$, 为治疗 HIV 的药物研发提供了新的线索 ${ }^{[35]}$; 提出了解析调控网络中直接与间接相互作用的数学 理论工具 ${ }^{[36]}$; 以及实现了对微小 RNA噪声调控效应 的观测和建模 ${ }^{[37]}$, 等等.

\section{4 组学数据推动下的癌症研究与精准医学}

癌症是人类健康的重大威胁, 最新统计数据表 明我国每年新发癌症病例数将高达约 430 万, 死亡人 数约 280 万 $^{[38]}$. 近年来, 基于组学技术的生物医学大 数据极大地促进了癌症的分子分型、分子标志物和药 物靶点等方面的研究进展, 也为揭示癌症的分子机 制提供了大量新的线索. 临床医学实践中对癌症的 诊疗主要是在器官、组织层面, 随着肿瘤生物学的研 究进展, 人们认识到要更好地实现癌症诊疗, 必须深 人到细胞、生物分子等多个层次去理解其生物学的机 制. 以癌症基因组图谱 (the cancer genome altas, TCGA)为代表的大规模癌症基因组学研究, 希望用 组学技术对多种癌症发生的分子变异进行系统的刻 画, 目前TCGA已完成约30种癌症约 15000 例临床样 本的多组学检测, 并对乳腺癌、大肠癌、肺癌等常见 癌症开展了系统的描述, 绘制了癌症分子变异图谱 (http://cancergenome.nih.gov/). 癌症基因组学研究还 有更大的目标, 就是希望从分子变异角度对癌症进 行重新分类定义 ${ }^{[39]}$.

癌症分子生物学与基因组学等方向的研究表明, 不同组织来源的癌症有很多共同的生物学基础, 如 持续增殖、基因组不稳定、免疫逃逸等 ${ }^{[40]}$. 人们提出 了泛癌症(pan-cancer)的概念：寻找泛癌症的分子变 
异可更好地找到驱动肿瘤发生发展的共同的生物学 机制, 也能对不同类型的癌症提供更系统的理解; 从 信息的角度考虑, 将不同癌症类型的分子数据放在 一起可显著提高样本数量, 有利于发现低频的具有 驱动作用的分子变异 ${ }^{[41 ~ 43]}$.

基因组学对癌症临床实践也有重要的贡献, 近 年来癌症靶向药物的快速研发, 使得基于分子变异 的癌症精准分型成为当前精准医学的核心. 比如, 针 对BRAF-V600E突变的靶向药对结肠癌、黑色素瘤等 多种癌症类型的突变携带患者均具有很好的疗效; 近 年来的明星药物, 作用于免疫检验点 (immune check point)PD1/PD-L1通路的抑制剂, 对具有丰富新生抗 原(neoantigen)的多种癌症有明显抑制作用 ${ }^{[44]}$. 一项 基于大规模组学数据的计算分析表明, 利用分子分 型, 可将已通过临床实验的靶向药物潜在受益人群 从 $5.9 \%$ 扩展到 $40.2 \%{ }^{[45]}$. 除了靶向药物, 基因组学数 据对常用化疗药也有一定的预测作用 ${ }^{[46]}$.

基因组学和系统生物学基础研究的迅速发展、基 因组检测技术的快速普及, 使得生物大数据在临床 医学上的大规模应用成为一个重要的发展趋势. 人 类基因组计划的一个主要初衷, 就是为复杂疾病的 研究建立基础. 在“向癌症宣战计划”和“人类基因组 计划”这两个美国政府主导生物医学发展的科学计划 之后, 2015年1月20日, 美国总统奥巴马宣布启动“精 准医学计划”, 致力于通过对健康记录和基因组信息 进行整合分析, 实现对癌症等疾病的个性化治疗. 2016年3月16日, 中国政府正式启动国家重点研发计 划精准医学研究重点专项, 旨在通过整合临床表型、 生命组学、影像组学等生物医学大数据, 实现对肿 瘤、罕见病、慢性病的个性化防沴治, 从整体上提高 我国的医学水平. 随着大规模组学数据的积累, 可以 期待我们对癌症的认识将会更加系统、深人, 癌症的 精准分型与用药将在临床上得到更加广泛的应用.

\section{5 宏基因组数据推动对人体和环境微生物 群落的新认识}

人体的健康不但取决于人自身的细胞和基因, 在人体体内和体表多个部位存在着大量微生物, 它 们是人体不可或缺的重要伙伴甚至是组成部分, 与 人体健康密切相关. 据估计, 这些微生物细胞总量可 能比人自身细胞总数多出一个数量级, 而它们所包
含的遗传物质总量则比人类基因组高 2 3个数量 级 ${ }^{[47]}$. 从这个意义上, 人体并不是单个物种的独立 个体, 而是由人和众多共生微生物组成的一个复杂 生态系统 ${ }^{[48]}$.

人体各部位上的微生物是一个复杂的群落, 通 常被称作“微生物组”(microbiome或microbiota). 一个 微生物群落中往往包含成百上千种微生物, 其中多 数很难分离和培养, 最有效的研究手段是对其中全 部遗传物质进行混合的DNA测序, 称作元基因组或 宏基因组(metagenome)测序. 有人把这个系统中来自 微生物的遗传信息总和称作我们的“第二基因组”[49]. 近十年来, 随着第二代高通量测序技术快速发展, 宏 基因组测序成为微生物组研究的主流方法, 大量数 据不断产生, 人们在此基础上发现了很多关于微生 物组构成与宿主健康状态之间的关联, 比如, 肥胖和 营养性疾病与微生物组的关系 ${ }^{[50,51]}$, 口腔疾病、消化 道疾病、糖尿病、癌症甚至是神经发育类疾病与微生 物组之间的关系 ${ }^{[52 ~ 56]}$, 等等. 同时, 人们已开始对微 生物组与人类代谢系统、免疫系统之间的相互作用机 理展开研究 ${ }^{[57 ~ 59]}$, 并尝试把改造微生物组构成作为 干预某些疾病的手段 ${ }^{[60]}$.

为了理解微生物组的基本规律, 多个国家和地 区设立了多个科学计划, 系统获取来自人体多个部 位的微生物组数据, 试图建立人类微生物组基本图 谱 $^{[61 ~ 63]}$. 在欧洲的EBI宏基因组数据库中, 已经包含 了来自全球 632 个微生物组项目的 10418 个宏基因组 和 1025 个宏转录组的数据样本. 这些进展充分说明 了微生物组对人类健康有重要作用, 同时也揭示出 宏基因组数据的高度复杂性和现有数据分析方法的 局限和不足. 2015年底, Science 和Nature杂志上分别 发表评述, 呼吁对微生物组及其信息学进行更系统 和深人的研究 ${ }^{[64 ~ 66]}$. 2016年5月, 美国启动了国家微生 物组计划, 对人体、植物、土壤、海洋和大气中的微 生物组开展大规模深人研究 (https://www.whitehouse. gov/the-press-office/2016/05/12/fact-sheet-announcingnational-microbiome-initiative).

\section{6 展望与讨论}

进人 21 世纪以来, 生物医学大数据的种类、性质 和内容都在不断拓展, 如何通过这些大数据获得出对 生命理解的大图景, 这不仅是Science 杂志的提问, 更 是整个科技界乃至全社会的提问. 回顾这短暂的十几 
年, 我们欣慰地看到, 不论是生物信息学与系统生物 学对生命基本规律的认识, 还是合成生物学对生命的 改造, 还是精准医学对人类疾病的控制和干预能力上, 都得到了快速的发展. 但是, 生命是高度复杂的系统, 人们对它的认识仍处在从局部走向全面的过程中, 对 于生命个体发育、疾病、生命的演化、生命与非生命 构成的生态系统等等, 人们的认识仍然刚刚开始. 获 取大量和多尺度的生物学和医学大数据并加以智能处 理与挖掘, 是加快这一认识过程的重要路径.

以高通量测序技术为代表的组学大数据已经为 生物学研究带来巨大变革. 随着这些技术的进步, 还 将不断催生新的衍生技术, 从不同角度和不同层次 解析基因的表达调控过程. 例如以单分子测序和单 细胞检测为代表的新技术, 将使我们能在前所未有 的精细尺度上解析生命过程. 而随着这些组学实验 成本的快速下降, 未来除了获取更多的样本外, 另一 个重点是对研究对象在不同的时间尺度上获取更多 的观测数据, 例如跟踪疾病的整个发生发展过程. 这 将为探索生物复杂现象的全貌和疾病的发生机理提 供重要的基础.

但是, 我们也必须清醒地认识到, 这些数据中包 含了巨大的宝藏, 但要有效地挖掘出这些宝藏, 还需 要大量艰苦的生物信息学与系统生物学理论、方法与 技术研究, 人们可以用越来越低的成本获得测序数 据, 而对数据的分析任务却变得越来越繁重和充满 挑战. 数据本身并不能产生知识, 只有有效地对数据 进行处理、分析和挖掘, 才能发挥出数据的价值. 值 得高兴的是, 近十几年来, 在组学数据大发展的同 时, 信息科学领域中以机器学习为代表的人工智能
技术和大数据计算和存储技术都有了突飞猛进的发 展, 将统计学、机器学习与大数据计算与生物组学大 数据有效地结合起来, 为我们探索生命的奥秘开拓 了广阔的天地.

应当看到, 以基因组学数据为代表的生物组学 大数据, 只是与生命相关的大数据中的一部分, 还有 很多其他类型的生物大数据, 例如近年来代谢组学 和蛋白质组学都取得了重要进展 ${ }^{[67,68]}$. 从人类医疗 健康角度看, 更多的和更普遍的数据是各种表型和 生理、病理数据. 随着信息技术在日常医疗健康领域 中的应用日益普及, 以电子病历、医学影像资料和新 近发展的各种可穿戴设备所记录的日常生理数据为 核心的医疗大数据, 包含了更大量的信息. 但是, 这 些信息的采集是日常医疗实践和健康体检过程中积 累起来的, 具有结构化程度弱、噪声大、不同医院甚 至不同科室之间技术衔接不佳等问题，而数据来源 和分布上比通过实验设计采集的数据具有更大的自 发性和随意性, 对数据处理和分析的方法都提出了 新的要求. 实现医院内部信息管理系统的互联互通 和数据整合, 进而从政府层面对地区乃至全国的海 量医院管理数据进行深度挖掘, 已经在医疗政策、医 保管理等领域展现出迫切需求和极大的潜在价值. 通过大数据技术手段整合各种生物组学大数据, 以 及临床表型、影像组学、医院管理、公共卫生等医学 大数据, 再使用统计分析、自然语言处理、影像分析、 深度学习与模式识别、智能搜索推荐等人工智能技术 对这些数据进行深度挖掘, 将使生物和医疗大数据 早日迈向造福于人民健康的知识大发现, 这必将成 为人类医疗健康事业发展的必由之路.

\section{参考文献}

1 International Human Genome Sequencing Consortium. Initial sequencing and analysis of the human genome. Nature, 2001, 409: 860-921

2 Pennisi E. How will big pictures emerge from a sea of biological data. Science, 2005, 309: 94

3 The 1000 Genomes Project Consortium. An integrated map of genetic variation from 1092 human genomes. Nature, 2012, 491: 56-65

4 Tennessen J A, Bigham A W, O'Connor T D, et al. NHLBI exome sequencing project, evolution and functional impact of rare coding variation from deep sequencing of human exomes. Science, 2012, 337: 64-69

5 Mailman M D, Feolo M, Jin Y M, et al. The NCBI dbGaP database of genotypes and phenotypes. Nat Genet, 2007, 39: 1181-1186

6 Bamshad M J, Ng S B, Bigham A W, et al. Exome sequencing as a tool for Mendelian disease gene discovery. Nat Rev Genet, 2011, 12: $745-755$

7 Kiezun A, Garimella K, Do R, et al. Exome sequencing and the genetic basis of complex traits. Nat Genet, 2012, 44: 623-630

8 Dewey F E, Grove M E, Pan C, et al. Clinical interpretation and implications of whole-genome sequencing. J Am Med Assoc, 2014, 311: 1035-1045

9 Cirulli E T, Goldstein D B. Uncovering the roles of rare variants in common disease through whole-genome sequencing. Nat Rev Genet, 
2010, 11: 415-425

$10 \mathrm{Ng} \mathrm{S} \mathrm{B}$, Buckingham K J, Lee C, et al. Exome sequencing identifies the cause of a Mendelian disorder. Nat Genet, 2010, 42: 30-35

11 Sanders S J, Murtha M T, Gupta A R, et al. De novo mutations revealed by whole-exome sequencing are strongly associated with autism. Nature, 2012, 485: 237-241

12 Cirulli E T, Lasseigne B N, Petrovski S, et al. Exome sequencing in amyotrophic lateral sclerosis identifies risk genes and pathways. Science, 2015, 347: 1436-1441

13 Smith B N, Ticozzi N, Fallini C, et al. Exome-wide rare variant analysis identifies TUBA4A mutations associated with familial ALS. Neuron, 2014, 84: 324-331

14 Purcell S M, Moran J L, Fromer M, et al. A polygenic burden of rare disruptive mutations in schizophrenia. Nature, 2014, 506: 185-190

15 Peloso G M, Auer P L, Bis J C, et al. Association of low-frequency and rare coding-sequence variants with blood lipids and coronary heart disease in 56000 whites and blacks. Am J Human Genet, 2014, 94: 223-232

16 Lohmueller K E, Spars $\varnothing$ T, Li Q, et al. Whole-exome sequencing of 2000 Danish individuals and the role of rare coding variants in type 2 diabetes. Am J Human Genet, 2013, 93: 1072-1086

17 Diogo D, Kurreeman F, Stahl E A, et al. Rare, low-frequency, and common variants in the protein-coding sequence of biological candidate genes from GWASs contribute to risk of rheumatoid arthritis. Am J Human Genet, 2013, 92: 15-27

18 Sobreira N L M, Cirulli E T, Avramopoulos D, et al. Whole-genome sequencing of a single proband together with linkage analysis identifies a Mendelian disease gene. PLoS Genet, 2010, 6: e1000991

19 Lupski J R, Reid J G, Gonzaga-Jauregui C, et al. Whole-genome sequencing in a patient with Charcot-Marie-Tooth neuropathy. New Engl J Med, 2010, 362: 1181-1191

20 Veeramah K R, O’Brien J E, Meisler M H, et al. De novo pathogenic SCN8A mutation identified by whole-genome sequencing of a family quartet affected by infantile epileptic encephalopathy and SUDEP. Am J Human Genet, 2012, 90: 502-510

21 Michaelson J J, Shi Y, Gujral M, et al. Whole-genome sequencing in autism identifies hot spots for de novo germline mutation. Cell, 2012, 151: 1431-1442

22 Jiang Y, Yuen R K C, Jin X, et al. Detection of clinically relevant genetic variants in autism spectrum disorder by whole-genome sequencing. Am J Human Genet, 2013, 93: 249-263

23 Martin H C, Kim G E, Pagnamenta A T, et al. Clinical whole-genome sequencing in severe early-onset epilepsy reveals new genes and improves molecular diagnosis. Human Mol Genet, 2014, 23: 3200-3211

24 Willig L K, Petrikin J E, Smith L D, et al. Whole-genome sequencing for identification of Mendelian disorders in critically ill infants: A retrospective analysis of diagnostic and clinical findings. Lancet Resp Med, 2015, 3: 377-387

25 Gaj T, Gersbach C A, Barbas C F. ZFN, TALEN, and CRISPR/Cas-based methods for genome engineering. Trends Biotechnol, 2013, 31: 397-405

26 Karginov F V, Hannon G J. The CRISPR system: Small RNA-guided defense in bacteria and archaea. Mol Cell, 2010, 37: 7-19

27 Jinek M, Chylinski K, Fonfara I, et al. A programmable dual-RNA-guided DNA endonuclease in adaptive bacterial immunity. Science, 2012, 337: 816-821

28 Liang P, Xu Y, Zhang X, et al. CRISPR/Cas9-mediated gene editing in human tripronuclear zygotes. Protein Cell, 2015, 6: 363-372

29 Shalem O, Sanjana N E, Hartenian E, et al. Genome-scale CRISPR-Cas9 knockout screening in human cells. Science, 2014, 343: 84-87

30 Shi J, Wang E, Milazzo J P, et al. Discovery of cancer drug targets by CRISPR-Cas9 screening of protein domains. Nat Biotechnol, 2015, 33: 661-667

31 Davidson E A, Windram O P, Bayer T S. Building synthetic systems to learn nature's design principles. Adv Exp Med Biol, 2012, 751: 411-429

32 Yuan Y, Liu B, Xie P, et al. Model-guided quantitative analysis of microRNA-mediated regulation on competing endogenous RNAs using a synthetic gene circuit. Proc Natl Acad Sci USA, 2015, 112: 3158-3163

33 Weinberger L S, Burnett J C, Toettcher J E, et al. Stochastic gene expression in a lentiviral positive-feedback loop: HIV-1 Tat fluctuations drive phenotypic diversity. Cell, 2005, 122: 169-182

34 Weinberger L S. A minimal fate-selection switch. Curr Opin Cell Biol, 2015, 37: 111-118

35 Dar R D, Hosmane N N, Arkin M R, et al. Screening for noise in gene expression identifies drug synergies. Science, 2014, 344: $1392-1396$

36 Kang T, Moore R, Li Y, et al. Discriminating direct and indirect connectivities in biological networks. Proc Natl Acad Sci USA, 2015, 112: $12893-12898$

37 Schmiedel J M, Klemm S L, Zheng Y, et al. MicroRNA control of protein expression noise. Science, 2015, 348: 128-132

38 Chen W, Zheng R, Baade P D, et al. Cancer statistics in China, 2015. CA Cancer J Clin, 2016, 66: 115-132 
39 Hoadley K A, Yau C, Wolf D M, et al. Multiplatform analysis of 12 cancer types reveals molecular classification within and across tissues of origin. Cell, 2014, 158: 929-944

40 Hanahan H, Weinberg R A. Hallmarks of cancer: The next generation. Cell, 2011, 144: 646-674

41 Weinstein J N, Collisson E A, Mills G B, et al. The Cancer Genome Atlas Pan-Cancer analysis project. Nat Genet, 2013, 45: 1113-1120

42 Lawrence M S, Stojanov P, Mermel C H, et al. Discovery and saturation analysis of cancer genes across 21 tumour types. Nature, 2014 , 505: 495-501

43 Zack T I, Schumacher S E, Carter S L, et al. Pan-cancer patterns of somatic copy number alteration. Nat Genet, 2013, 45: 1134-1140

44 McGranahan N, Furness A J S, Rosenthal R, et al. Clonal neoantigens elicit T cell immunoreactivity and sensitivity to immune checkpoint blockade. Science, 2016, 351: 1463-1469

45 Rubio-Perez C, Tamborero D, Schroeder M P, et al. In silico prescription of anticancer drugs to cohorts of 28 tumor types reveals targeting opportunities. Cancer Cell, 2015, 27: 382-396

46 Ding Z, Zu S, Gu J. Evaluating the molecule-based prediction of clinical drug responses in cancer. Bioinformatics, 2016, doi: 10.1093/bioinformatics/btw344

47 Gill S R, Pop M, DeBoy R T, et al. Metagenomic analysis of the human distal gut microbiome. Science, 2006, 312: 1355-1359

48 Gordon J I. Honor thy gut symbionts redux. Science, 2012, 336: 1251-1253

49 Grice E A, Segre J A. The human microbiome: Our second genome. Ann Rev Genom Human Genet, 2012, 13: 151-170

50 Turnbaugh P J, Hamady M, Yatsunenko T, et al. A core gut microbiome in obese and lean twins. Nature, 2009, 457: 480-484

51 Smith M I, Yatsunenko T, Manary M J, et al. Gut microbiomes of Malawian twin pairs discordant for Kwashiorkor. Science, 2013, 339: $548-554$

52 Wang J, Qi J, Zhao H, et al. Metagenomic sequencing reveals microbiota and its functional potentials associated with periodontal disease. Sci Rep, 2013, 3: 1843

53 Qin J, Li R, Raes J, et al. A human gut microbial gene catalogue estabblished by metagenomic sequencing. Nature, 2010, 464: 59-65

54 Qin J, Li Y, Cai Z, et al. A metagenome-wide association study of gut microbiota in type 2 diabetes. Nature, 2012, 490: 55-60

55 Sears C L, Garrett W S. Microbes, microbiota, and colon cancer. Cell Host Microbe, 2014, 15: 317-328

56 Hsiao E Y, McBride S W, Hsien S, et al. Microbiota modulate behavioral and physiological abnormalities associated with neurodevelopmental disorders. Cell, 2013, 155: 1451-1463

57 Nicholson J K, Holmes E, Kinross J, et al. Host-gut microbiota metabolic interactions. Science, 2012, 336: 1262-1267

58 Maurice C F, Haiser H J, Turnbaugh P J. Xenobiotics shape the physiology and gene expression of the active human gut microbiome. Cell, 2013, 152: 39-50

59 Yano J M, Yu K, Donaldson G P, et al. Indigenous bacteria from the gut microbiota regulate host serotonin biosynthesis. Cell, 2015, 161: 264-276

60 Borody T J, Khoruts A. Fecal microbiota transplantation and emerging applications. Nat Rev Gastroent Hepatol, 2012, 9: 88-96

61 The Human Microbiome Project Consortium. A framework for human microbiome research. Nature, 2012, 486: 215-221

62 Zhou X, Brown C J, Abdo Z, et al. Differences in the composition of vaginal microbial communities found in healthy Caucasian and black women. ISME J, 2007, 1: 121-133

63 Arumugam M, Raes J, Pelletier E, et al. Enterotypes of the human gut microbiome. Nature, 2011, 473: 174-180

64 van Opstal E J, Bordenstein S R. Rethinking heritability of the microbiome. Science, 2015, 349: 1172-1174

65 Alivisatos A P, Blaser M J, Brodie E L, et al. A unified initiative to harness Earth's microbiomes. Science, 2015, 350: 507-508

66 Dubilier N, McFall-Ngai M, Zhao L. Create a global microbiome effort. Nature, 2015, 526: 631-634

67 Patti G J, Yanes O, Siuzdak G. Innovation: Metabolomics: the apogee of the omics trilogy. Nat Rev Mol Cell Biol, 2012, 13: 263-269

68 Jain K K. Role of proteomics in the development of personalized medicine. Adv Protein Chem Struct Biol, 2016, 102: 41-52 


\title{
From big biological data to big discovery: The past decade and the future
}

\author{
ZHANG XueGong, JIANG Rui, WANG XiaoWo, GU Jin \& CHEN Ting \\ ${ }^{1}$ Department of Automation, Department of Computer Science and Technology, and School of Life Sciences, MOE Key Laboratory of Bioinformat- \\ ics, Tsinghua University, Beijing 100084, China; \\ ${ }^{2}$ Bioinformatics Division, Tsinghua National Laboratory for Information Science and Technology, Beijing 100084, China; \\ ${ }^{3}$ Center for Medical and Health Big Data, Tsinghua Institute for Data Sciences, Beijing 100084, China
}

The quick accumulation of biological and medical big data is an important characteristic of current life sciences. Typical representatives of such big data are omics data obtained with the so-called next-generation sequencing or NGS technology, including genomic data, epigenomic data, metagenomic data, transcriptomics data, etc. The amount of data is overwhelming, but our key interest is whether such big data can lead to big discovery on the rules or mechanisms behind life. The question "how will big pictures emerge from a sea of biological data" was asked as one of the 125 most challenging questions by the Science magazine in 2005. Now more than ten years have passed. This article provides a brief review and perspective on the development of next-generation DNA sequencing technology in the past decade, as well as its applications and impacts on the fields of medical genetics, synthetic biology, precision medicine and microbiome studies. The big biological data have already brought new discoveries in biology although yet more will be expected and such discoveries have already shown promising applications in medical practices. The wide availability of DNA sequencing especially its rapidly decreasing cost is revolutionizing the study of genetic diseases. Large-scale genome-wide association studies (GWAS) and exome-sequencing studies have discovered many genes that are associated with many types of diseases. Some have already began to be used in clinical diagnosis. Accompanying the development of technologies for reading genomes, the genome editing technology shows the other side of the story: editing and writing genomes. Such technologies are enabling the systematic understanding of complex biological systems, and point to promising new approaches for disease treatment and prevention. Cancer studies are a major field that benefited the most from omics data. People are gaining more and more understanding in the development of cancer, and new taxonomy of cancer types based on genomic and epigenomic data brings the hope toward the goal of precision medicine. NGS also brought big data of metagenome of human microbiomes. Such data have revealed the importance of microbiota to many aspects of human health.

Big biological data have brought many advancement in life sciences and will lead to more scientific breakthroughs in the future. To achieve this, bioinformatics has been playing a major role in turning data to information, and turning information to knowledge. Omics data are only type of the data for human health. Phenotypical data including data in medical records are equally or more important. It can be expected that the integrative analyses of omics data and medical phenotype data will bring more new discoveries for precision medicine research and practice. Methodology research on integrating and mining big biological and medical data will be crucial for such discoveries.

big biological data, genomics, bioinformatics, systems biology, omics

doi: 10.1360/N972016-00900 


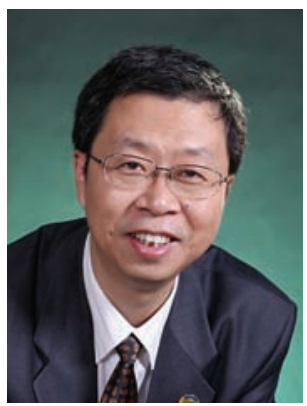

\section{强学工}

1989 年毕业于清华大学自动化系, 1994 年于清华大学获模式识别与智能系统 专业博士学位, 现为清华大学自动化系教授, 生命科学学院和医学院兼职教 授, 清华信息国家实验室生物信息学研究部主任, 清华大学合成与系统生物 学中心执行主任, 生物信息学教育部重点实验室副主任, 自动化系学术委员 会主任, 清华大学学术委员会委员, 中国人工智能学会生物信息学与人工生 命专业委员会主任、中国生物工程学会生物信息学与计算生物学专业委员会 常务副主任、中国生物物理学会生物信息学与理论生物物理专业委员会副主任. 2001 2002 年赴美国哈佛大学公共卫生学院进修. 2006 年获国家杰出青年科学 基金, 是国家级精品课程主讲人, 2009 年获国家级教学成果二等奖, 2011 年成 为国家重点基础研究发展计划(973 计划)首席科学家. 主要研究方向是模式识 别与生物信息学, 包括: 生物大数据分析与机器学习、新一代测序数据的处理 和分析、基因选择性剪接及其调控、微生物群落信息结构与功能分析等. 